\section{Review}

Correspondence

Andrey P. Anisimov

anisimov@obolensk.org

\title{
Treatment of plague: promising alternatives to antibiotics
}

\author{
Andrey P. Anisimov ${ }^{1}$ and Kingsley K. Amoako ${ }^{2}$ \\ ${ }^{1}$ Laboratory for Plague Microbiology, Department of Infectious Diseases, State Research \\ Center for Applied Microbiology and Biotechnology, 142279 Obolensk, Serpukhov District, \\ Moscow Region, Russia \\ ${ }^{2}$ Canadian Food Inspection Agency, Animal Diseases Research Institute, P.O. 640, Township \\ Road 9-1, Lethbridge, AB T1J 3Z4, Canada
}

\begin{abstract}
Plague still poses a significant threat to human health, and interest has been renewed recently in the possible use of Yersinia pestis as a biological weapon by terrorists. The septicaemic and pneumonic forms are always lethal if untreated. Attempts to treat this deadly disease date back to the era of global pandemics, when various methods were explored. The successful isolation of the plague pathogen led to the beginning of more scientific approaches to the treatment and cure of plague. This subsequently led to specific antibiotic prophylaxis and therapy for $Y$. pestis. The use of antibiotics such as tetracycline and streptomycin for the treatment of plague has been embraced by the World Health Organization Expert Committee on Plague as the 'gold standard' treatment. However, concerns regarding the development of antibiotic-resistant $Y$. pestis strains have led to the exploration of alternatives to antibiotics. Several investigators have looked into the use of alternatives, such as immunotherapy, non-pathogen-specific immunomodulatory therapy, phage therapy, bacteriocin therapy, and treatment with inhibitors of virulence factors. The alternative therapies reported in this review should be further investigated by comprehensive studies of their clinical application for the treatment of plague.
\end{abstract}

\section{Overview}

As a Gram-negative bacterium, the causative agent of plague, Yersinia pestis (Yersin, 1894), has been the cause of three pandemics (Achtman et al., 1999; Drancourt et al., 2004; Guiyoule et al., 1994; Raoult et al., 2000), and has led to the deaths of millions of people, the devastation of cities and villages, and the collapse of governments and civilizations (Zietz \& Dunkelberg, 2004). At the present time, the circulation of $Y$. pestis has been detected within the populations of more than 200 species of wild rodent inhabiting natural plague foci on all continents, except for Australia and Antarctica, and the transmission of plague is provided for by a minimum of 80 species of flea. Plague epizootics, during which the pathogen spreads through new territories, alternate with a decrease in epizootic activity. When natural foci of infection are investigated during periods between epizootics, no antibodies to $Y$. pestis are detected in the animals, and the plague microbe is not detected by bacteriological and biological methods. Morbidity in humans is noted, as a rule, when epizootics become acute, and is a consequence of bites of fleas, direct contact with infected animal tissues, the consumption of insufficiently cooked meat products, or the inhalation of

Abbreviations: DIC, diffuse intravascular coagulation; WHO, World Health Organization. aerosolized respiratory excreta of animals or patients with the pneumonic form of infection (Anisimov, 2002a, b; Anisimov et al., 2004; Aparin \& Golubinskii, 1989; Brubaker, 1991; Butler, 1983; Dennis et al., 1999; Domaradskii, 1993, 1998; Gage \& Kosoy, 2005; Hinnebusch, 2003; Inglesby et al., 2000; Lien-Teh et al., 1936; Naumov \& Samoilova, 1992; Nikolaev, 1972; Perry \& Fetherston, 1997; Pollitzer, 1954).

Plague remains a serious problem for international public health. Small outbreaks of plague continue to occur throughout the world, and at least 2000 cases of plague are reported annually (Gage \& Kosoy, 2005). Plague has recently been recognized as a reemerging disease, and $Y$. pestis, if used by the aerosol route of exposure as a bioterrorism agent, could cause mass casualties (Gage \& Kosoy, 2005; Inglesby et al., 2000). According to World Health Organization (WHO) data, if $50 \mathrm{~kg}$ of the plague pathogen was released as an aerosol over a city with a population of 5 million, 150000 people might fall ill with pneumonic plague, 36000 of whom would die (WHO, 1970).

Immunization against plague is one of the major approaches being pursued to deal with potential infection. Commercially available human plague vaccines are based on either a live, attenuated strain or a killed, whole-cell preparation. The live, attenuated vaccine is produced in 
the former Soviet Union, and is based on $Y$. pestis strain EV, line NIIEG. This strain is attenuated due to deletion of the $102 \mathrm{~kb}$ pgm locus that includes the hms locus responsible for the ability to store haemin, and a cluster of genes needed for production of the siderophore-based yersiniabactin biosynthetic/transport systems. The parental wild-type strain was isolated in Madagascar. The second vaccine is a formalinfixed virulent $Y$. pestis strain 195/P (originally isolated in India) that was developed in the USA, although at present it is manufactured only in Australia. Both these types of vaccines have unacceptable side effects when used (Meyer, 1970; Naumov et al., 1992). A number of subunit-based vaccines are currently under development and/or at different stages of preclinical/clinical trials. These offer the advantage of employing a defined antigen that possesses the ability to elicit high-level protection, and they are also less reactogenic than the currently used whole-cell vaccines (Anisimov et al., 2004; Williamson, 2001; Williamson et al., 2005). The main limitation of the prevention of plague by vaccination is that protection is delayed for at least 1 week after immunization, and this time may be crucial with respect to the lethal outcome of the disease (Butler, 1983; Dennis et al., 1999; Domaradskii, 1993, 1998; Inglesby et al., 2000; Lien-Teh et al., 1936; Naumov \& Samoilova, 1992; Nikolaev, 1972; Perry \& Fetherston, 1997; Pollitzer, 1954; Rudnev, 1940). As a consequence, antibiotics are employed for the early initiation of prophylaxis and therapy of plague.

The overwhelming majority of $Y$. pestis natural isolates are susceptible in vitro and in vivo to antimicrobials such as tetracycline, doxycycline, ciprofloxacin, streptomycin, gentamicin, chloramphenicol, fluoroquinolones, sulphonamides, and trimethoprim-sulfamethoxazole (Domaradskii, 1993; Frean et al., 2003; Inglesby et al., 2000). The infrequent recovery of natural drug-resistant isolates of $Y$. pestis has been explained by the relative rarity of cases of human plague at the present time and by the acute nature of the disease (Domaradskii, 1993). However, a 'natural' strain with resistance to multiple antibiotics, including all of those recommended for plague prophylaxis and treatment, was isolated in 1995 in the Ambalavao district of Madagascar from a 16-year-old boy. The $Y$. pestis strain 17/95 was resistant to ampicillin, chloramphenicol, kanamycin, streptomycin, spectinomycin, sulfonamides, tetracycline and minocycline. The resistance genes were carried by a plasmid that could conjugate with high frequency to other $Y$. pestis strains in vitro (Galimand et al., 1997) or in fleas (Hinnebusch et al., 2002). The possibility of the rise of such multidrug-resistant strains in the natural environment, the ease of generation of such strains under laboratory conditions (Hinnebusch et al., 2002; Hurtle et al., 2003), the potential use of such strains for bioterrorist attack, together with the rapidity and high lethality of the disease (Butler, 1983; Dennis et al., 1999; Domaradskii, 1993, 1998; Inglesby et al., 2000; Lien-Teh et al., 1936; Naumov \& Samoilova, 1992; Nikolaev, 1972; Perry \& Fetherston, 1997; Pollitzer, 1954; Rudnev, 1940), are evidence of the necessity for a search for novel antimicrobial alternatives to antibiotics.
Here, we will briefly review the existing methods, as well as promising current strategies under investigation for the treatment of plague.

\section{Pathogenesis and virulence factors}

For constant circulation in natural foci, the plague pathogen must penetrate into the host organism, counteract the protective bactericidal systems of the rodent, and reproduce to ensure bacteraemia, essential for further transmission of the infection by fleas to a new host. In the case of a human pneumonic plague outbreak, the bacteria must also overcome host innate immunity to develop pneumonia with abundant exhalation of $Y$. pestis, causing plague pneumonia in naïve persons. Each of these stages in the cyclic existence of $Y$. pestis is supported by numerous factors of the plague pathogen, including pathogenicity factors and housekeeping genes (Table 1), which may exert an influence, jointly or individually, upon various stages of the infectious process or transmission. The removal of any one of these components may or may not render the organism avirulent. However, only in aggregate do these factors ensure survival of $Y$. pestis in the host organism, no matter how significant or insignificant their individual effect might be (Anisimov et al., 2004; Brubaker, 1991; Perry \& Fetherston, 1997).

The main pathogenicity factor of Yersinia resides in the complex traits encoded by the plasmid pCad (also termed $\mathrm{pCD}, \mathrm{pVW}, \mathrm{pYV}$ or $\mathrm{pLcr}$ ), the presence of which in the cell is essential for the manifestation of virulence (Portnoy \& Falkow, 1981). It is considered as the Yop virulon: the system that permits extracellular bacteria to disarm the cells involved in the host immune response, disrupt their binding, and induce their apoptosis by injection of bacterial effector proteins. This system consists of the Yop proteins and the apparatus of their type III secretion, called Ysc. The Ysc apparatus consists of 25 proteins, while most of the Yops can be divided into two groups according to their functions. Some of them are intracellular effectors (YopE, YopH, YpkA/YopO, YopP/YopJ, YopM, YopT), whereas others (YopB, YopD, LcrV) form the translocation apparatus, which is unfolded on the surface of the bacterium to deliver the effectors into eukaryotic cells through the plasma membrane. The secretion of Yops proteins is triggered by contact with eukaryotic cells. In the absence of attachment, yersiniae do not release Yops from the bacterial cell. The adhesion mechanism is not yet known, but it seems that close contact with eukaryotic membrane lipids alone might be enough to trigger secretion. The secretion channel may be blocked at different levels by proteins of the virulon, including YopN, TyeA and LcrG, which cover the bacterial secretory channel, presumably in the form of a trap door. The precise functioning of the system also requires several chaperones, called Syc proteins, that assist Yops to be secreted by the injectisome. Each of these chaperones serves only one Yop, and they do not leave the bacterial cytosol. Transcription of the genes is controlled by the temperature and activity of the secretion apparatus (Cornelis, 2002; Viboud \& Bliska, 2005). 
Table 1. Selected factors ensuring survival of $Y$. pestis in the host organism

Compiled from Anisimov, 2002a, b, Anisimov et al., 2004; Brubaker, 1991; Oyston et al., 2000; Perry \& Fetherston, 1997; Robinson et al., 2005; Sing et al., 2002; Sodhi et al., 2004. ND, Not determined.

\begin{tabular}{|c|c|c|c|c|}
\hline \multirow[t]{2}{*}{ Bacterial factor } & \multirow[t]{2}{*}{ Function or activity } & \multicolumn{3}{|c|}{$\begin{array}{l}\text { Reported decrease of virulence } \\
\text { in knock-outs (by order of magnitude) }\end{array}$} \\
\hline & & Dramatic $(>)$ & Moderate (4-2) & Low $(2-0)$ \\
\hline \multicolumn{5}{|l|}{ Pathogenicity factors } \\
\hline $\begin{array}{l}\text { Low-calcium response (LCR) } \\
\text { stimulon [bacterial } \\
\text { virulence-associated } \\
\text { type III secretion (T3S) } \\
\text { system; Yersinia } \\
\text { outer-membrane proteins } \\
\text { (Yop) virulon] } \\
\text { including: }\end{array}$ & $\begin{array}{l}\text { System permitting extracellular yersiniae } \\
\text { to counteract the non-specific } \\
\text { immune response by an impairment } \\
\text { of phagocytic and signalling activity } \\
\text { of macrophages and induction of apoptosis } \\
\text { of phagocytic cells (delivery of toxic } \\
\text { bacterial proteins, Yops, from extracellularly located } \\
\text { bacteria into the eukaryotic cell cytosol) }\end{array}$ & + & - & - \\
\hline LcrV & $\begin{array}{l}\text { Yop translocator; inhibition of chemotaxis } \\
\text { of neutrophils; suppression } \\
\text { of the synthesis of } \gamma \text {-interferon and tumour } \\
\text { necrosis factor } \alpha \text { : cytokines necessary } \\
\text { for non-specific activation of professional } \\
\text { phagocytes and the formation } \\
\text { of productive granulomas, by stimulation } \\
\text { of interleukin (IL)-10 production; } \\
\text { a repressor of the cytokines indicated above; } \\
\text { inhibition of LPS-induced } \\
\text { production of IL-1 } \beta \text { in macrophages; competition } \\
\text { with LPS for toll-like receptor } 2 \text { binding }\end{array}$ & + & - & - \\
\hline YopD & Yop translocator & ND & ND & ND \\
\hline YopE & $\begin{array}{l}\text { Antiphagocytic; actin depolymerization; } \\
\text { inactivation of Rho proteins }\end{array}$ & + & - & - \\
\hline YopH & $\begin{array}{l}\text { Antiphagocytic; protein tyrosine phosphatase; induction } \\
\text { of apoptosis; inhibition of lymphocyte proliferation }\end{array}$ & + & - & - \\
\hline YopM & $\begin{array}{l}\text { Disruption of thrombin interaction } \\
\text { with thrombocytes and hindering } \\
\text { of their aggregation, essential } \\
\text { for the formation of a blood clot }\end{array}$ & + & - & - \\
\hline YopP/YopJ & $\begin{array}{l}\text { Down-regulation of the inflammatory } \\
\text { response of macrophages, epithelial } \\
\text { and endothelial cells by blocking the mitogen-activated } \\
\text { protein kinase and nuclear factor- } \kappa \mathrm{B} \text { pathways }\end{array}$ & - & - & + \\
\hline YopT & $\begin{array}{l}\text { Antiphagocytic; inactivation of Rho proteins; } \\
\text { depolymerization of actin stress fibres }\end{array}$ & ND & ND & ND \\
\hline YpkA/YopO & $\begin{array}{l}\text { Antiphagocytic; inactivation of Rho proteins; } \\
\text { autophosphorylating serine/threonine kinase }\end{array}$ & ND & $\mathrm{ND}$ & $\mathrm{ND}$ \\
\hline YscF & $\begin{array}{l}\text { Formation of the external needle of the } \\
\text { T3S system; participation in virulence } \\
\text { protein secretion, in translocation } \\
\text { of virulence proteins across eukaryotic } \\
\text { membranes and in the cell contact- } \\
\text { and calcium-dependent regulation of T3S }\end{array}$ & ND & ND & ND \\
\hline
\end{tabular}


Table 1. cont.

\begin{tabular}{|c|c|c|c|c|}
\hline \multirow[t]{2}{*}{ Bacterial factor } & \multirow[t]{2}{*}{ Function or activity } & \multicolumn{3}{|c|}{$\begin{array}{l}\text { Reported decrease of virulence } \\
\text { in knock-outs (by order of magnitude) }\end{array}$} \\
\hline & & Dramatic $(>)$ & Moderate (4-2) & Low $(2-0)$ \\
\hline Plasminogen activator (Pla) & $\begin{array}{l}\text { Spreading factor that promotes generalization } \\
\text { of infection, possesses } \\
\text { proteolytic properties and determines } \\
\text { the fibrinolytic }\left(37^{\circ} \mathrm{C}\right) \text { and plasmocoagulase } \\
\left(28^{\circ} \mathrm{C}\right) \text { activities of the plague pathogen; } \\
\text { post-translational degradation of Yop proteins; } \\
\text { adhesive and invasive activity }\end{array}$ & + & + & $+^{\star}$ \\
\hline pH 6 antigen (PsaA) & Antiphagocytic; adhesive activity & + & + & - \\
\hline $\begin{array}{l}\text { Capsular antigen } \\
\text { fraction I (F1; Caf1) }\end{array}$ & Antiphagocytic; adhesive activity & + & + & + \\
\hline Ail & $\begin{array}{l}\text { Adhesive activity; resistance to bactericidal } \\
\text { action of normal sera }\end{array}$ & - & - & - \\
\hline Yersinia 'murine' toxin $(\mathrm{Ymt})$ & $\begin{array}{l}\text { Development of toxic shock } \\
\text { (lethal effect on mice and rats); } \\
\text { reinforcement of endotoxic shock in mammals }\end{array}$ & - & - & + \\
\hline LPS & $\begin{array}{l}\text { Development of endotoxic shock; } \\
\text { resistance to the action } \\
\text { of bactericidal cationic peptides } \\
\text { and normal sera; adhesive activity }\end{array}$ & + & - & - \\
\hline \multicolumn{5}{|l|}{$\begin{array}{l}\text { Factors responsible } \\
\text { for nutrient } \\
\text { requirements and } \\
\text { housekeeping genes }\end{array}$} \\
\hline $\begin{array}{l}\text { Yersiniabactin transport } \\
\text { and biosynthesis }\end{array}$ & Siderophore-dependent iron-transport system & + & - & - \\
\hline Haemin storage $(\mathrm{Hms})$ & Adsorption of haemin on microbial cell surface & - & - & + \\
\hline Purine biosynthetic enzymes & De novo synthesis of purines & + & - & - \\
\hline Dam & DNA adenine methylation & - & + & - \\
\hline $\begin{array}{l}\text { Two-component regulatory } \\
\text { system PhoPQ }\end{array}$ & Activation of resistance to innate immune defences & - & - & + \\
\hline
\end{tabular}

${ }^{\star}$ More than one + indicates the existence of conflicting data reported by different researchers.

Infective doses of 10 bacteria or less are sufficient to cause lethal infection in naïve rodents and primates via the intradermal, subcutaneous and intravenous routes (Anisimov et al., 2004; Brubaker, 1991; Perry \& Fetherston, 1997). $\mathrm{LD}_{50}$ values in the case of the respiratory and oral routes of infection increase to $10^{2}-10^{4}$ c.f.u. (Anisimov, 2002a; Anisimov et al., 2004; Ehrenkranz \& Meyer, 1955) and $10^{5}-10^{9}$ c.f.u. (Anisimov, 2002a), respectively.

Y. pestis is primarily a rodent pathogen, and is usually transmitted to another mammalian host by fleas, following the death of the rodent. After being introduced into the host, the bacterium is initially susceptible to phagocytosis and killing by neutrophils (Cavanaugh \& Randall, 1959) and $\mathrm{CD}_{11 \mathrm{c}^{+}}$cells (Bosio et al., 2005), but it may survive and multiply within macrophages. Released bacteria are resistant to capture by neutrophils and begin an unchecked propagation (Cavanaugh \& Randall, 1959). The bacteria then spread from the initial flea-bite site to the lymph nodes, where local replication causes a suppurative lymphadenitis (bubo). If the lymphatic system becomes overwhelmed, septicaemia results, with $Y$. pestis spreading to other organs. The LPS of $Y$. pestis causes the development of endotoxic shock peculiar to other Gram-negative infections (Butler, 1983; Dmitrovskii, 1994; Van Amersfoort et al., 2003). After the development of highly contagious plague pneumonia, the disease spreads in the air in droplets (Lien-Teh, 1926; Lien-Teh et al., 1936; Rudnev, 1940).

\section{Clinical manifestations}

There are three main primary forms of human plague, bubonic, septicaemic and pneumonic. Complications such as secondary septicaemic plague, secondary pneumonic 
plague, plague meningitis, plague endophthalmitis and multiple lymph node involvement result from bacteraemic dissemination of the pathogen (Butler, 1983; Dennis et al., 1999; Lien-Teh et al., 1936; Naumov \& Samoilova, 1992; Nikolaev, 1972; Pollitzer, 1954; Rudnev, 1940). Septicaemia may be followed by digital gangrene (Kuberski et al., 2003).

Irrespective of clinical form, the mean incubation period is 3-6 days, but may decrease to 1-2 days in patients with primary septicaemic or pneumonic plague, and increase in vaccinated people. All of the clinical forms may be characterized by sudden onset of illness, malaise, chills and temperature increase up to $39-40{ }^{\circ} \mathrm{C}$, headache, myalgia, insomnia, indistinct speech, wobbly walk, and sometimes vomiting. In the case of serious illness, patients are delirious, and violent and aggressive. Attempts to make an escape from a patient care institution may be considered as a sign of developing meningitis. In extremely severe cases, a profound prostration and cyanosis can be observed.

Fatality for untreated bubonic plague varies from 40 to $60 \%$, while untreated septicaemic and pneumonic forms of the disease are always lethal (Albizo \& Surgalla, 1970; Butler, 1983; Dennis et al., 1999; Dmitrovskii, 1994; Kool, 2005; Krishna \& Chitkara, 2003; Lien-Teh, 1926; Lien-Teh et al., 1936; Naumov \& Samoilova, 1992; Nikolaev, 1972; Pollitzer, 1954; Rudnev, 1940).

\section{Bubonic plague}

Bubonic plague results from a flea bite or direct contact of an open skin lesion with plague-infected material. Sometimes, a vesicle, pustule or ulcer develops at the inoculation site. $Y$. pestis spreads via the lymphatic vessels to the regional lymph nodes, causing inflammation and swelling in one or several nodes: buboes ('bubo' is derived from the Greek 'boubon', groin). Buboes are usually no greater than $5 \mathrm{~cm}$ in diameter, extremely tender, erythematous, and surrounded by a boggy haemorrhagic area. Buboes typically arise in the inguinal and femoral regions, but also occur in other regional lymph node sites, including popliteal, axillary, supraclavicular, cervical, post-auricular, pharyngeal and other sites. Deeper nodes (such as intrabdominal or intrathoracic nodes) may also be involved through the lymphatic or haematogenous spread of $Y$. pestis. Initial symptoms include malaise, high fever, and one or more painful lymph nodes. Pulse rate is increased to $110-140 \mathrm{~min}^{-1}$. Blood pressure is low, usually about $100 / 60 \mathrm{~mm} \mathrm{Hg}$, due to extreme vasodilatation. Circulatory collapse, haemorrhage and peripheral thrombosis are the terminal events (Butler, 1983; Dennis et al., 1999; Lien-Teh et al., 1936; Naumov \& Samoilova, 1992; Nikolaev, 1972; Pollitzer, 1954; Rudnev, 1940).

\section{Septicaemic plague}

Septicaemic plague may occur primarily as a result of infection with massive doses of the pathogen, or when the bacillus is deposited in the vasculature, bypassing the lymphatics. In this case, bacteria proliferate in the body without producing a bubo. Secondary septicaemic plague is a complication of haematogenous dissemination of bubonic plague. The presenting signs and symptoms of primary septicaemic plague are essentially the same as those of any Gram-negative septicaemia: fever, chills, nausea, vomiting and diarrhoea. Later, purpura, disseminated intravascular coagulation, and acral cyanosis and necrosis may be seen. Other symptoms include abdominal pain and digital gangrene (Albizo \& Surgalla, 1970; Butler, 1983; Dennis et al., 1999; Dmitrovskii, 1994; Lien-Teh et al., 1936; Naumov \& Samoilova, 1992; Nikolaev, 1972; Pollitzer, 1954; Rudnev, 1940; Van Amersfoort et al., 2003).

\section{Pneumonic plague}

Pneumonic plague is rare, but is the most dangerous and fatal form of the disease, and is spread via respiratory droplets. It can develop as a secondary complication of septicaemic plague or result from the inhalation of infectious respiratory excreta of humans or animals with the pneumonic form of infection. The onset of pneumonic plague is acute and fulminant, with high fever, chills, headache, malaise, myalgia and productive cough (with sputum that may be clear, bloody or purulent) within $24 \mathrm{~h}$ of the onset of symptoms. Buboes on the neck are rare, but are a symptom of pneumonic plague. Nausea, diarrhoea, vomiting and abdominal pain may also accompany the disease. The pneumonia progresses rapidly, resulting in dyspnoea, stridor and cyanosis. The disease rapidly engulfs the lungs and haemorrhages develop, filling them with fluid (a haemorrhagic pneumonia). The terminal events are respiratory failure, circulatory collapse, and bleeding diathesis (Albizo \& Surgalla, 1970; Butler, 1983; Dennis et al., 1999; Dmitrovskii, 1994; Kool, 2005; Krishna \& Chitkara, 2003; Lien-Teh, 1926; Lien-Teh et al., 1936; Naumov \& Samoilova, 1992; Nikolaev, 1972; Pollitzer, 1954; Rudnev, 1940).

\section{Methods of plague treatment}

Until the nineteenth century, the treatment of plague was based on mysticism and superstition. Such 'remedies' as magic and talismans, mixtures of bird and animal blood, tablets made from rattlesnake meat, and even material squeezed from fresh horse dung, were widely used (Afanas'ev \& Vaks, 1903). Later, methods such as phlebotomy, emetics, purgatives and diaphoretics were also applied to plague treatment (Rudnev, 1940). The isolation of the plague pathogen, $Y$. pestis, in 1894 (Yersin, 1894) made possible scientific approaches to the cure of plague-infected patients. The local application of antiseptics such as iodine, mercuric chloride, carbolic acid or quinine, together with the incision or even searing of bubos, were promising in some cases, as were attempts to surmount severe systemic disease by the use of the same remedies, specific bacteriophages or animal hyperimmune sera (LienTeh et al., 1936; Rudnev, 1940); however, real success in plague therapy was observed when sulfanilamides (Carman, 1938) and then streptomycin (Hornibrook, 1946) became available. 


\section{Antibiotic prophylaxis and therapy}

Currently, antibiotics are the cornerstone of plague treatment. The antibiotic prophylaxis and therapy for $Y$. pestis infection, as suggested by the WHO Expert Committee on Plague (1970), focuses on the use of tetracycline, streptomycin, and chloramphenicol for eradication of the organism. More recently, the US Working Group on Civilian Biodefence has added gentamicin, doxycycline and ciprofloxacin to this list (Inglesby et al., 2000). Chloramphenicol is optional for the treatment of plague meningitis (Becker et al., 1987). Aminoglycosides (streptomycin, kanamycin, tobramycin, gentamicin and amikacin) and cephalosporins (ceftriaxone and ceftazidim) are recommended for the treatment of plague caused by F1negative $Y$. pestis strains that are resistant to doxycycline, ampicillin and cefoperazone in vivo. Studies in mice suggest that an increase in the daily doses of less-efficient drugs such as cefotaxime, cefoperazone, sulbactam/ampicillin, azthreonam, ciprofloxacin and rifampicin, along with prolongation of the treatment course for up to 7 days, make it possible to increase the protective effects to $80-100 \%$ (Anisimov et al., 2004; Ryzhko et al., 1998). Furthermore, studies using ciprofloxacin, doxycycline and the newer fluoroquinolones gatifloxacin and moxifloxacin have shown an increase in the survival of mice presenting with pneumonic plague (Byrne et al., 1998; Russell et al., 1998; Steward et al., 2004).

It is recommended that antibiotic therapy be started as early as possible. A delay in antibiotic therapy will result in an increase in bacterial biomass, and in a more harmful subsequent inflammatory response caused by endotoxin release induced by both lytic and non-lytic antimicrobials (Nau \& Eiffert, 2002). During the first few hours of antibiotic treatment, patients should be monitored closely, because shock may develop after the start of antibiotic application due to bacteriolysis, with the subsequent release of large amounts of endotoxin (Jacobs et al., 1990). Those in contact with pneumonic plague patients and persons who have been exposed to aerosols should receive doxycycline, ciprofloxacin or chloramphenicol as post-exposure prophylaxis (Inglesby et al., 2000). The recent increase in multidrug-resistant strains (Galimand et al., 1997; Wong et al., 2000) has led to renewed efforts to find alternatives to antibiotics.

\section{Immunotherapy}

Serum therapy. A. Yersin and others were the first to use the serum of vaccinated rabbits to cure infected animals (Yersin et al., 1895). In 1896, Yersin was able to cure several patients in Asia with a horse serum (Yersin, 1897). However, the experiences of other researchers with the use of plague serum were conflicting. The horse, mule or bull sera were produced in different laboratories with the use of different immunization schemes involving killed or live bacteria of different strains. In the course of treatment, patients were injected subcutaneously or intravenously with up to $1000 \mathrm{ml}$ immune serum $(200-500 \mathrm{ml}$ for one subcutaneous or intramuscular injection, and
50-100 $\mathrm{ml}$ for one intravenous injection). In the case of bubonic plague, the reported death rate in treated $(13 \%)$ and untreated $(64 \%)$ patients differed significantly. In patients with septicaemic or pneumonic plague, treatment did not cause a detectable decrease in mortality. The sooner treatment was started the better the result. Even in patients that succumbed to infection, an up to twofold increase in time to death was usually reported. The dangers of serum sickness and anaphylactic shock frequently induced by serum therapy were believed to be less significant than that of septic shock (Lien-Teh et al., 1936; Pollitzer, 1954; Rudnev, 1940). In 1970, the WHO Expert Committee on Plague recommended the continuation of further development of plague antitoxic sera that might be used for the treatment of plague patients with severe toxicosis (WHO, 1970).

Antibody therapy. Beginning in the 1960s, separate antibody preparations were introduced into clinical practice for preventing and treating infectious diseases. In contrast to older remedies based on animal sera, these specific immunoglobulins contained antibodies derived from immunized human donors, and so had minimal side effects. Although human-specific globulins lack the toxicities associated with animal sera, they have several limitations, such as high cost, low availability, and the potential to transmit infectious disease (Buchwald \& Pirofski, 2003; Casadevall, 2002; 2005; Keller \& Stiehm, 2000).

Hybridoma technology, introduced in 1975 (Kohler \& Milstein, 1975), provides a method for the unlimited production of homogeneous mAbs. The construction of mouse-human chimeric or humanized mAbs (Morrison, 1992), completely human mAbs (Kang et al., 1991) from hybridomas or combinatorial libraries, and recombinant human polyclonal antibodies (Bregenholt \& Haurum, 2004), makes it possible to reduce the immunogenicity of rodent mAbs in humans. These approaches provide the possibility of raising relevant antibodies against protective antigens only, and even against protective epitopes of protective antigens.

In the case of $Y$. pestis, several antigens have been shown to be able to produce protective immunity. Among them are F1 capsular antigen (Meyer et al., 1974; Simpson et al., 1990), LcrV or simply V antigen (Leary et al., 1995; Motin et al., 1994; Une \& Brubaker, 1984), YopD (Andrews et al., 1999), and type III secretion system needle complex protein, YscF (Matson et al., 2005). Immunodominant epitopes have been found for the F1 (Sabhnani \& Rao, 2000; Sabhnani et al., 2003; Zav'yalov et al., 1995) and V (Hill et al., 1997) antigens. Passive administration of antibodies against target antigens protects macrophages from $Y$. pestis-induced cell death, promotes phagocytosis (Cowan et al., 2005; Philipovskiy et al., 2005; Weeks et al., 2002), and protects animals against both bubonic and pneumonic plague (Anderson et al., 1997; Friedlander et al., 1995; Green et al., 1999; Hill et al., 2006; Motin et al., 1994; Roggenkamp 
et al., 1997; Une \& Brubaker, 1984; Williamson et al., 2005). Importantly, therapy based on a single antibody against a single antigen or epitope will be ineffective in the case of infection with a virulent strain lacking the antigen or expressing a different serological variant of the antigen (Anisimov et al., 2004; Friedlander et al., 1995; Roggenkamp et al., 1997).

Non-pathogen-specific immunomodulatory therapy. $Y$. pestis is known to efficiently overcome the innate immune system of many mammals. However, it has been shown that neutrophils (Cavanaugh \& Randall, 1959) and $\mathrm{CD}_{11 \mathrm{c}^{+}}$cells (Bosio et al., 2005), which represent the initial line of host defence against invading pathogens, play an important role in suppressing the initial replication and dissemination of inhaled Y. pestis. Recent studies (Liles, 2001) conducted in vitro and in vivo have shown that granulocyte colony-stimulating factor, granulocytemacrophage colony-stimulating factor and interferon- $\gamma$ can augment the functional antimicrobial activities of neutrophils. Studies conducted in animal models have shown the potential use of each of these cytokines for the treatment of bacterial infections. We can speculate that such adjunctive treatment may be useful for plague therapy.

$Y$. pestis mediates septic shock, which contributes significantly to host death (Butler, 1983; Dmitrovskii, 1994). Sepsis and the systemic inflammatory response syndrome are accompanied by the inability to regulate the inflammatory response (Van Amersfoort et al., 2003). The most potent class of cholesterol-lowering drugs, statins, has been shown to also possess cholesterol-independent effects, including diverse immunomodulatory and anti-inflammatory properties (Almog, 2003). Recent studies have demonstrated that simvastatin (Merx et al., 2004) and cerivastatin (Ando et al., 2000) pretreatment profoundly improves survival in a murine model of sepsis. Another retrospective study has shown that statin therapy reduces both overall and attributable mortality in patients with bacteraemia (Liappis et al., 2001). The lipid profiles of the statin-pretreated patients were considerably higher than those of the no-statin group, and it has been suggested that the medicinal efficacy is a result of the attenuation of the intensity of the inflammatory response due to binding of endotoxins by increased amounts of lipids (Almog et al., 2004).

Several other immune response modifiers that target different stages of innate immunity and might be useful for plague therapy have recently been reviewed (AmlieLefond et al., 2005; Masihi, 2000), but only one, glutoxim, a sulfur-containing hexapeptide with an immunomodulatory effect on lymphocytes (Fimiani et al., 2002), has been used in an animal model of plague (Zhemchugov, 2004). When injected into mice $(12.5 \mathrm{mg}$ per animal) $6 \mathrm{~h}$ before challenge with $10 \mathrm{LD}_{50}$ of the virulent $Y$. pestis strain 231, it protected half of the animals from death. Glutoxim has also been shown to protect mice from tularaemia and melioidosis. However, the data thus far are inconclusive, as they were obtained in isolated experiments that employed a minimal number of laboratory animals.

\section{Phage therapy}

Bacteriophages seem to be good candidates for antibacterial therapy: they often possess high species specificity, they are non-toxic to eukaryotes, and they kill the target bacteria that they infect and within which they multiply. After the discovery of bacteriophages by Twort in 1915, and independently by d'Herelle in 1917, a number of researchers and physicians were overenthusiastic in the use of bacteriophages for the therapy of bacterial disease (Skurnik \& Strauch, 2006; Sulakvelidze, 2005; Summers, 1999, 2001). With respect to plague, in 1925, d'Herelle used a highly virulent anti-plague phage that had been isolated in 1920 in Indo-China from rat faeces to treat four cases of bubonic plague as the first bacteriophage therapy (d'Herelle, 1925). All the patients had laboratory-diagnosed bubonic plague with very serious clinical signs. d'Herelle treated all four with anti-plague phage preparations by single/double direct injection of phage $(0 \cdot 5-1 \mathrm{ml})$ into the buboes. Within several hours of injection, the patients felt better, a $2{ }^{\circ} \mathrm{C}$ average fall in temperature was recorded, and severe pain in the buboes decreased. All four patients recovered in what was considered a remarkable fashion. On the basis of this work, a number of attempts to confirm the efficacy of the phage therapy of plague both in animal models and in clinical trials were performed (d'Herelle, 1925; Flu, 1929; Fonquernie, 1932; Lien-Teh et al., 1936; Naidu \& Avari, 1932; Rudnev 1940). However, a poor understanding of the mechanisms of phage-bacterial interactions, including lysogeny and phage DNA restriction, and poorly designed and executed experiments and clinical trials, together with the use of undefined phages in the form of non-purified phage preparations, led to conflicting results (Skurnik \& Strauch, 2006; Sulakvelidze, 2005; Summers, 1999, 2001).

Bacteriophages have received renewed attention as possible agents against bacterial pathogens. Evidence from several recent trials designed and executed in accordance with good laboratory practice (GLP) regulations indicates that phage therapy can be effective, although the efficacy of the phage treatment depends greatly on the route (oral, intramuscular, aerosol spray, etc.) and/or frequency of phage application (Skurnik \& Strauch, 2006; Sulakvelidze, 2005; Summers, 1999, 2001). Numerous obstacles to the use of phage as antimicrobials for clinical practice remain. Among them are the issue of phage resistance, and the possibility of phagemediated transfer of undesirable genetic material to bacterial hosts. Therapy based on the simultaneous use of several phages with known genetic sequences and targeting different bacterial receptors can help in overcoming these obstacles. Currently, the genomes of several Y. pestis-specific phages have been sequenced (Filippov et al., 2005; Garcia et al., 2003), and they could be candidates for the revival of plague phage therapy. 
A phage-encoded peptidoglycan-degrading activity is responsible for the cell-wall-hydrolysing action of bacteriophages. At least four types of these enzymes, endolysins, are responsible for this activity in different phages (Young, 1992). Taking into account that if a sufficiently high phage dose is given, phages are able to control infection through a non-proliferative lytic mechanism (Berchieri et al., 1991; Goode et al., 2003), the therapeutic use of endolysins in a controlled fashion seems advantageous in comparison with the uncontrollable increase of the live active agent.

\section{Bacteriocin therapy}

Bacteriocins, bacterially produced antimicrobial peptides, range from the well-studied, narrow spectrum, highmolecular-mass colicins produced by Escherichia coli and the short polypeptide lantibiotics of lactic acid bacteria to the relatively unknown halocins produced almost universally by halobacteria. Purified bacteriocins could be used for the reduction or elimination of certain pathogens (Braude \& Siemienski, 1965; Riley \& Wertz, 2002). It has been shown in assays for potency that purified colicins $\mathrm{V}$ and $\mathrm{K}$ have similar inhibitory activities on a per weight basis to those of the therapeutic antibiotics kanamycin, streptomycin and oxytetracycline (McGeachie, 1970). Bacteriocins nisin A (produced by Lactococcus lactis) and mutacin B-Ny266 (produced by Streptococcus mutans) are as active as vancomycin and oxacillin against most strains tested (Bacillus, Enterococcus, Lactococcus, Listeria, Mycobacterium, Pediococcus, Staphylococcus, Bordetella, Clostridium, Peptostreptococcus, Propionibacterium, Streptococcus and Micrococcus). Furthermore, mutacin B-Ny266 remains active against strains that are resistant to nisin A, oxacillin and vancomycin (MotaMeira et al., 2000).

Intraperitoneal injections of mutacin B-Ny266 have been used for the treatment of mice infected with Staphylococcus aureus. While there was $100 \%$ mortality in the control group of mice, no mortality was observed in the mice injected with vancomycin or mutacin B-Ny266 (MotaMeira et al., 2005). Lacticin 3147, a broad-spectrum bacteriocin produced by the food-grade organism L. lactis, reduced the incidence of mastitis after experimental challenge with Streptococcus dysgalactiae in non-lactating dairy cows (Ryan et al., 1999). Local injections of staphylococcin A-1262a were used to treat 50 patients with a variety of staphylococcal lesions. Complete recovery was observed in 42 of the patients (Lachowicz, 1965). The streptococcal bacteriocin tomicide was used for protection of white mice from staphylococcal infection. Tomicide, administered in the maximum dose admissible for mice, ensured the protection of up to two-thirds of the total number of mice. A single oral administration of the preparation immediately after infection protected onethird of the surviving mice from local staphylococcal infection (Blinkova et al., 2003). The pronounced prophylactic effect of tomicide, manifested by a reliable decrease of group A streptococcal carrier state, as well as by a decrease in morbidity in respiratory streptococcal infection among children in a test group in comparison with controls, has been reported (Briko \& Zhuravlev, 2004). Enterocoliticin, a phage-tail-like bacteriocin, has been administered as an antimicrobial compound by the oral route for the treatment of BALB/c mice infected with Yersinia enterocolitica, the nearest relative of $Y$. pestis. The increase in the number of $Y$. enterocolitica c.f.u. in animals was retarded at time points shortly after the application of enterocoliticin, indicating that the bacteriocin was effective during the early phase of infection (Damasko et al., 2005). A purified class IIa bacteriocin, secreted by Paenibacillus polymyxa NRRL-B30509, has been incorporated into chicken feed, and dramatically reduced both intestinal levels and the frequency of chicken colonization by Campylobacter jejuni (Stern et al., 2005). The same bacteriocin has been shown to inhibit the growth of Y. pestis in vitro (E. A. Svetoch and B. V. Eruslanov, personal communication) in doses similar to those recommended by the WHO Expert Committee on Plague (WHO, 1970) for antibiotics. The above studies suggest that there is a potential therapeutic effect associated with bacteriocins. When contemplating the clinical use of bacteriocins, one important consideration is their possible pathological effects. In early studies with partially purified bacteriocins (Montgomerie et al., 1973; Tagg \& McGiven, 1972; Turnowsky et al., 1973) or strain pairs differing in their expression (Brubaker et al., 1965; Burrows, 1965; Smith, 1974), the data showed their potential toxicity, and also a relationship between the carriage of bacteriocinogenic factors and the virulence of certain strains. However, studies with purified substances have in many cases failed to confirm toxicity (Braude \& Siemienski, 1965; Tagg et al., 1976). Although intraperitoneal injection of $10 \mathrm{mg}$ mutacin B-Ny266 kg ${ }^{-1}$ did not apparently affect the health of mice, these results will have to be confirmed with more relevant toxicity tests (Mota-Meira et al., 2005). The investigation of the in vitro cytotoxicities of two bacteriocins, gallidermin (Staphylococcus gallinarum) and nisin A, in comparison with those of antimicrobial peptides of eukaryotic origin, magainin I, magainin II and melittin, indicated that gallidermin was the least cytotoxic antimicrobial peptide, followed by nisin A, magainin I, magainin II and melittin. Nisin caused haemolysis, but at concentrations which were 1000 -fold higher than those required for antimicrobial activity. Gallidermin shows the most promise as a therapeutic agent, with relatively low cytotoxicity and potent antimicrobial activities (Maher \& McClean, 2006). In considering the potential toxicity of bacteriocins, the well-known toxicity of antibiotics such as quinolones, doxycycline, streptomycin and gentamicin, and the possible problems associated with massive use of antimicrobial agents for prophylaxis or therapy during a bioterrorist attack, should be noted (Navas, 2002).

\section{Inhibitors of virulence factors}

Virulence refers to the ability of an organism to establish an infection and cause disease. Many steps are involved in the infection process, including adherence, invasion and the evasion of host defences (Finlay \& Falkow, 1997). Microbial 
factors involved in the process of virulence are unique, in that their inhibition, by definition, should interfere with the process of infection rather than with bacterial viability. Inhibitors of such targets would be unlikely to affect host cells, to be cross-resistant to existing therapies, or to induce resistance themselves. Bacterial virulence may therefore offer unique opportunities to inhibit the establishment of infection or alter its course as a method of antimicrobial chemotherapy (Alksne, 2002; Y. M. Lee et al., 2003; Marra, 2004).

A necessary step in the successful colonization and, ultimately, production of disease by microbial pathogens is the ability to adhere to host surfaces (Finlay \& Falkow, 1997), in many cases involving oligosaccharides located on the host cell surface and bacterial adhesins. The terminal di- or trisaccharide units of these oligosaccharides may be used to inhibit these interactions, preventing attachment and therefore disease. The validity of this approach has been unequivocally demonstrated in experiments performed in a wide variety of animals, from mice to monkeys, and also in humans (Ofek et al., 2003).

Y. pestis expresses a range of adhesins, including $\mathrm{pH} 6$ (PsaA), F1 (Caf1), Pla and S-layer protein (Anisimov, 2002b; Kienle et al., 1992; Parkhill et al., 2001; Payne et al., 1998). pH 6 antigen binds to several human immunoglobulin G subclasses by acting as a bacterial $\mathrm{Fc}$ receptor (Zav'yalov et al., 1996). It is also able to bind to gangliotetraosylceramide, gangliotriaosylceramide and lactosylceramide, and also to attach to hydroxylated galactosylceramide. Recombinant $\mathrm{pH} 6$ antigen, present on the surface of intact $E$. coli cells, possesses the same specificity as the purified antigen, with the exception of binding to non-hydroxylated galactosylceramide. The observed binding patterns indicate that the presence of $\beta 1$-linked galactosyl residues in glycosphingolipids is the minimum requirement for binding of the $\mathrm{pH} 6$ antigen. The glycosphingolipids recognized by the $\mathrm{pH} 6$ antigen are common and may be found on a range of host cell types (Payne et al., 1998). In fact, $\mathrm{pH} 6$ antigen preparations are able to agglutinate human, rabbit, guinea pig and murine erythrocytes (Bichowsky-Slomnicki \& BenEfraim, 1963). Studies that are currently in progress in the Laboratory for Plague Microbiology, Department of Infectious Diseases, State Research Center for Applied Microbiology and Biotechnology, indicate that $\mathrm{pH} 6$ antigen is capable of promoting the adhesion of macrophage-like eukaryotic cells to each other and to plastic surfaces, and the formation of cell monolayers. The high-molecular-weight capsular antigen $\mathrm{F} 1$ possesses haemagglutinating activity on account of its ability to bind specifically to D-galactosamine$\mathrm{HCl}$ and glucuronic acid (Anisimov, 2002b). An analysis of the complete genome of $Y$. pestis has revealed the presence of eight more gene clusters similar to the operons psa and cafl, each of which is potentially capable of promoting the expression of the pilus adhesins (Parkhill et al., 2001). Transfer of the pla locus, which encodes the production of the plasminogen activator Pla, to E. coli cells imparted adhesive activity to the latter with respect to a number of eukaryotic cells (Kienle et al., 1992), on account of the ability of Pla to bind to the mammalian extracellular matrix (Lähteenmäki et al., 1998). Y. pestis S-layer protein at a concentration of 8-16 $\mu \mathrm{g} \mathrm{ml}^{-1}$ agglutinated rabbit erythrocytes; this agglutination was inhibited by $0 \cdot 1 \mathrm{M}$ sugars: rhamnose (fourfold) and dulcitol (eightfold) (Diatlov \& Antonova, 1999). Until recently it was customarily considered that the plague pathogen had lost the ability to synthesize adhesin/invasin Ail on account of the insertion of IS285 (Brubaker, 2004); however, in the genome of the $Y$. pestis virulent strain CO92, this gene is intact (Parkhill et al., 2001). More recently, the $Y$. pestis genome has been shown to possess two homologues to the Erwinia HecA adhesin (Rojas et al., 2002). Y. pestis lipopolysaccharide is also reported to be an adhesin (Straley, 1993).

$Y$. pestis, as a species associated with pneumonic infections, adheres more efficiently to an alveolar epithelial A549 cell line than enteric bacteria, including enteric yersiniae. The plague pathogen demonstrates a restricted tropism for oligosaccharides compared with environmental and opportunistic bacteria. It has been shown that the compound with the greatest anti-adhesion activity toward A549 cells is $p$ nitrophenol (Thomas \& Brooks, 2004). As an alternative to antibiotics, the inhibition of attachment can be mediated through the use of oligosaccharide receptor mimics. In a more recent report, Thomas \& Brooks (2006) have demonstrated that the attachment of $Y$. pestis strain GB to the murine monocyte cell line J774A.1 and a range of human respiratory epithelial cell lines is reduced by $55-65 \%$ after pre-treatment of the cell lines with tunicamycin (an inhibitor of the biosynthesis and processing of $N$-linked oligosaccharides, produced by Streptomyces lysosuperificus). This further demonstrates the potential of oligosaccharides as anti-adhesion therapeutics. Other generic attachment inhibitors include polymeric saccharides (dextran and heparin), GalNAc $\beta 1-4 \mathrm{Gal}, \quad$ GalNAc $\beta 1-3 \mathrm{Gal}, \quad \mathrm{Gal} \beta 1-$ 4 GlcNAc and Gal $\beta 1-3 \mathrm{GlcNAc}$ (Thomas \& Brooks, 2004). It is possible that mixtures of such compounds may serve as a novel class of therapeutics for respiratory tract infections, including pneumonic plague.

The Ysc-Yop-'type III' weaponry delivering effector proteins into the cytosol of the eukaryotic target cell seems to be the main pathogenicity factor of Yersinia. Inhibitors specifically targeting type III secretion are attracting attention (Chen et al., 2003; K. Lee et al.; 2003, 2005; Kauppi et al., 2003a,b; Nordfelth et al., 2005; Xie et al., 2004). The majority of them target YopH, protein tyrosine phosphatase (Chen et al., 2003; K. Lee et al., 2003, 2005; Xie et al., 2004) or YopE, a GTPase-activating protein (Kauppi et al., 2003b). Among such inhibitors are compounds that belong to a class of acylated hydrazones of different salicylaldehydes (Nordfelth et al., 2005), monoanionic squaric acids (Xie et al., 2004), peptidic $\alpha$-ketocarboxylic acids, and sulfonamides (Chen et al., 2003). A eukaryotic cell model that mimics in vivo conditions has shown that some of the inhibitors attenuate the pathogen to the advantage of the host cell. 
Iron is a necessary nutrient for all pro- and eukaryotic cells, and at physiological $\mathrm{pH}$ values, iron salts $\left(\mathrm{Fe}^{3+}\right)$ form an almost-insoluble ferric hydroxide, $\mathrm{Fe}(\mathrm{OH})_{3}$. To assimilate the negligible portion of the iron that is still present in the dissolved state, both in the mammalian organism and in micro-organisms, special iron-binding molecules, siderophores, are synthesized. Bacterial siderophores have a critical role in the competition between parasite and host for iron acquisition (Braun, 2001; Finlay \& Falkow, 1997). Therefore, the $Y$. pestis siderophore yersiniabactin, as well as its receptor Psn (Perry \& Fetherston, 1997), are promising targets for the development of new antimicrobial inhibitors to treat plague. An inhibitor of the domain salicylation enzymes required for siderophore biosynthesis in $Y$. pestis, the arylic acyl adenylate analogue $5^{\prime}-\mathrm{O}-[\mathrm{N}$-(salicyl)-sulfamoyl] adenosine, has recently been designed, synthesized, and shown to inhibit yersiniabactin biosynthesis and the growth of $Y$. pestis under iron-limiting conditions (Ferreras et al., 2005). More recently, a set of newly synthesized aryl sulfamoyl adenosine derivatives has also been shown to inhibit yersiniabactin biosynthesis in vitro (Miethke et al., 2006).

Other possible targets for inhibiting $Y$. pestis virulence are quorum sensing (Suga \& Smith, 2003), the two-component regulatory systems (Oyston et al., 2000; Winfield et al., 2005) that govern virulence, and/or the enzymes for the biosynthesis of the LPS that is believed to determine antimicrobial-cationic-peptide (Anisimov et al., 2005; Bengoechea et al., 1998) and serum resistance (Anisimov et al., 2005; Porat et al., 1995).

\section{Symptomatic treatment}

Severe cases of plague are characterized by shock and extensive diffuse intravascular coagulation (DIC), two interrelated processes that have common causal mechanisms and reinforce each other (Hardaway, 1982). The standard treatment of the pathophysiological changes accompanying endotoxic shock and DIC consists of administration of fluid and vasopressors to restore blood pressure and organ blood flow, and oxygenation (Cohen \& Glauser, 1991; Naumov \& Samoilova, 1992; Rackow \& Astiz, 1991; Wheeler \& Bernard, 1999).

Very important to the management of shock is early fluid resuscitation and the immediate start of mechanical ventilation (Carcillo et al., 1991). In addition to extensive capillary leakage, severe plague cases are characterized by severe cardiac depression (Albizo \& Surgalla, 1970; Butler, 1983; Dennis et al., 1999; Dmitrovskii, 1994; Lien-Teh et al., 1936; Naumov \& Samoilova, 1992; Nikolaev, 1972; Pollitzer, 1954; Rudnev, 1940; Van Amersfoort et al., 2003). Consequently, pulmonary congestion may develop early, and this limits the amount of fluid that can be administered. In general, inotropic and vasopressive support is needed from an early stage. Dobutamine is preferred for its beneficial effects on cardiac function and peripheral oxygenation (Vincent et al., 1990; Winslow et al., 1973).
As for the anti-DIC therapy, currently the only undoubtedly successful treatment is anti-shock therapy. Bleeding due to DIC should probably be treated with replacement therapy: platelets for thrombocytopenia, cryoprecipitate for hypofibrinogenaemia and fresh frozen plasma for decreased coagulation factors (Jacobson \& Young, 1986). DIC may cause severe distal necrosis (Welty et al., 1985), and if gangrene has completely demarcated then plastic surgery or amputation may be needed (Kuberski et al., 2003). In the case of evolving gangrene, in a patient with good peripheral blood supply and no bleeding diathesis, sympathetic blockade to preserve peripheral feet tissues has been shown to be successful (Kuberski et al., 2003).

\section{Concluding remarks}

The treatment dynamics of plague are of critical interest because of the high human mortality rate of the disease, and current threat for use in bioterrorism. Even though antibiotics such as ciprofloxacin, doxycycline and the newer fluoroquinolones have shown an increase in survival in mice presenting with pneumonic plague, there has recently been a worrying increase in multidrug-resistant $Y$. pestis strains. This has necessitated the need to look at alternatives to antibiotics as treatment regimens for plague. This review has highlighted some of the promising nonantibiotic therapeutic strategies that can be explored further. Thus, a novel treatment mechanism of pneumonic plague infection may be via inhibiting adhesion of $Y$. pestis to the respiratory tract. Recent progress in the use of short-chain oligosaccharides as potential anti-adhesion therapeutics, and also a set of newly synthesized aryl sulfamoyl adenosine derivatives as inhibitors of yersiniabactin biosynthesis, make these receptor mimics potential alternatives to antibiotics. Although hopes remain high that these alternative strategies of plague treatment, alone or as part of combination therapies, will provide a valuable new line of defence against multdrug-resistant $Y$. pestis strains, they remain a long way from clinical practice. The alternative therapies reported in this review should be investigated by comprehensive studies of their clinical applications as a form of preparedness against any possible bioterrorist attack involving the use of antibiotic-resistant $Y$. pestis.

\section{Acknowledgements}

This work was partially funded by US Civilian Research and Development Foundation (CRDF) grant RBO-11012-MO-01 (DOE/ $\mathrm{LAB}$ agreement $325786-\mathrm{A}-\mathrm{K} 6$ ) and by the International Science and Technology Center (ISTC) grant 2927.

\section{References}

Achtman, M., Zurth, K., Morelli, G., Torrea, G., Guiyoule, A. \& Carniel, E. (1999). Yersinia pestis, the cause of plague, is a recently emerged clone of Yersinia pseudotuberculosis. Proc Natl Acad Sci U S A 96, 14043-14048. 
Afanas'ev, M. I. \& Vaks, P. B. (1903). Human Plague. St Petersburg, Russia: Modern Medicine and Hygiene Press (in Russian).

Albizo, J. M. \& Surgalla, M. J. (1970). Isolation and biological characterization of Pasteurella pestis endotoxin. Infect Immun 2, 229-236.

Alksne, L. E. (2002). Virulence as a target for antimicrobial chemotherapy. Expert Opin Investig Drugs 11, 1149-1159.

Almog, Y. (2003). Statins, inflammation, and sepsis: hypothesis. Chest 124, 740-743.

Almog, Y., Shefer, A., Novack, V., Maimon, N., Barski, L., Eizinger, M., Friger, M., Zeller, L. \& Danon, A. (2004). Prior statin therapy is associated with a decreased rate of severe sepsis. Circulation 110, 880-885.

Amlie-Lefond, C., Paz, D. A., Connelly, M. P., Huffnagle, G. B., Dunn, K. S., Whelan, N. T. \& Whelan, H. T. (2005). Innate immunity for biodefense: a strategy whose time has come. J Allergy Clin Immunol 116, 1334-1342.

Anderson, G. W., Worsham, P. L., Bolt, C., Andrews, G. P., Welkos, S., Friedlander, A. M. \& Burans, J. P. (1997). Protection of mice from fatal bubonic and pneumonic plague by passive immunization with monoclonal antibodies against the F1 protein of Yersinia pestis. Am J Trop Med 56, 471-473.

Ando, H., Takamura, T., Ota, T., Nagai, Y. \& Kobayashi, K. (2000). Cerivastatin improves survival of mice with lipopolysaccharideinduced sepsis. J Pharmacol Exp Ther 294, 1043-1046.

Andrews, G. P., Strachan, S. T., Benner, G. E., Sample, A. K., Anderson, G. W., Jr, Adamovicz, J. J., Welkos, S. L., Pullen, J. K. \& Friedlander, A. M. (1999). Protective efficacy of recombinant Yersinia outer proteins against bubonic plague caused by encapsulated and nonencapsulated Yersinia pestis. Infect Immun 67, 1533-1537.

Anisimov, A. P. (2002a). Factors of Yersinia pestis proving circulation and persistence of plague pathogen in ecosystems of natural foci. Communication 2. Mol Gen Mikrobiol Virusol 4, 3-11 (in Russian).

Anisimov, A. P. (2002b). Yersinia pestis factors, assuring circulation and maintenance of the plague pathogen in natural foci ecosystems. Report 1. Mol Gen Mikrobiol Virusol 3, 3-23 (in Russian).

Anisimov, A. P., Lindler, L. E. \& Pier, G. B. (2004). Intraspecific diversity of Yersinia pestis. Clin Microbiol Rev 17, 434-464 (erratum 17, 695).

Anisimov, A. P., Dentovskaya, S. V., Titareva, G. M. \& 9 other authors (2005). Intraspecies and temperature-dependent variations in susceptibility of Yersinia pestis to bactericidal action of serum and polymyxin B. Infect Immun 73, 7324-7331.

Aparin, G. P. \& Golubinskii, E. P. (1989). Plague Microbiology Manual. Irkutsk, USSR: Irkutsk State University (in Russian).

Becker, T. M., Poland, J. D., Quan, T. J., White, M. E., Mann, J. M. \& Barnes, A. M. (1987). Plague meningitis - a retrospective analysis of cases reported in the United States, 1970-1979. West J Med 147, 554-557.

Bengoechea, J.-A., Lindner, B., Seydel, U., Díaz, R. \& Moriyón, I. (1998). Yersinia pseudotuberculosis and Yersinia pestis are more resistant to bactericidal cationic peptides than Yersinia enterocolitica. Microbiology 144, 1509-1515.

Berchieri, A. J., Lovell, M. A. \& Barrow, P. A. (1991). The activity in the chicken alimentary tract of bacteriophages lytic for Salmonella typhimurium. Res Microbiol 142, 541-549.

Bichowsky-Slomnicki, L. \& Ben-Efraim, S. (1963). Biological activities in extracts of Pasteurella pestis and their relation to the 'pH 6 antigen'. J Bacteriol 86, 101-111.

Blinkova, L. P., Butova, L. G., Sergeev, V. V., Elkina, S. I., Al'tshuler, M. L. \& Kalina, N. G. (2003). Effectiveness of the oral administration of tomicide in experimental infection. Zh Mikrobiol Epidemiol Immunobiol 1, 74-77 (in Russian).

Bosio, C. M., Goodyear, A. W. \& Dow, S. W. (2005). Early interaction of Yersinia pestis with APCs in the lung. J Immunol 175, 6750-6756. Braude, A. I. \& Siemienski, J. S. (1965). The influence of bacteriocins on resistance to infection by Gram-negative bacteria. I. The effect of colicin on bactericidal power of blood. J Clin Invest 44, 849-859.

Braun, V. (2001). Iron uptake mechanisms and their regulation in pathogenic bacteria. Int J Med Microbiol 291, 67-79.

Bregenholt, S. \& Haurum, J. (2004). Pathogen-specific recombinant human polyclonal antibodies: biodefence applications. Expert Opin Biol Ther 4, 387-396.

Briko, N. I. \& Zhuravlev, M. V. (2004). Use of tomicid in prophylaxis of respiratory streptococcal infection in the organized groups of children of pre-school age. Zh Mikrobiol Epidemiol Immunobiol 4, 17-20 (in Russian).

Brubaker, R. R. (1991). Factors promoting acute and chronic disease caused by yersiniae. Clin Microbiol Rev 4, 309-324.

Brubaker, R. R. (2004). The recent emergence of plague: a process of felonious evolution. Microb Ecol 47, 293-299.

Brubaker, R. R., Beesley, E. D. \& Surgalla, M. J.(1965). Pasteurella pestis: role of pesticin I and iron in experimental plague. Science 149, 422-424.

Buchwald, U. K. \& Pirofski, L. (2003). Immune therapy for infectious diseases at the dawn of the 21 st century: the past, present and future role of antibody therapy, therapeutic vaccination and biological response modifiers. Curr Pharm Des 9, 945-968.

Burrows, T. W. (1965). A possible role for pesticin in virulence of Pasteurella pestis. Zentbl Bakteriol Parasitenkd Infektkr Hyg Abt 1 Orig Reihe A 196, 315-317.

Butler, T. (1983). Plague and Other Yersinia Infections. New York: Plenum.

Byrne, W. R., Welkos, S. L., Pitt, M. L. \& 7 other authors (1998). Antibiotic treatment of experimental pneumonic plague in mice. Antimicrob Agents Chemother 42, 675-681.

Carcillo, J. A., Davis, A. L. \& Zaritsky, A. (1991). Role of early fluid resuscitation in pediatric septic shock. JAMA (J Am Med Assoc) 266, 1242-1245.

Carman, J. A. (1938). Prontosil in the treatment of oriental plague. East Afr Med J 14, 362-366.

Casadevall, A. (2002). Passive antibody administration (immediate immunity) as a specific defense against biological weapons. Emerg Infect Dis 8, 833-841.

Casadevall, A. (2005). Antibody-based defense strategies against biological weapons. ASM News 71, 28-33.

Cavanaugh, D. C. \& Randall, R. (1959). The role of multiplication of Pasteurella pestis in mononuclear phagocytes in the pathogenesis of fleaborne plague. J Immunol 83, 348-363.

Chen, Y. T., Xie, J. \& Seto, C. T. (2003). Peptidic $\alpha$-ketocarboxylic acids and sulphonamides as inhibitors of protein tyrosine phosphatases. J Org Chem 68, 4123-4125.

Cohen, J. \& Glauser, M. P. (1991). Septic shock: treatment. Lancet 338, 736-739.

Cornelis, G. R. (2002). Yersinia type III secretion: send in the effectors. J Cell Biol 158, 401-408.

Cowan, C., Philipovskiy, A. V., Wulff-Strobel, C. R., Ye, Z. \& Straley, S. C. (2005). Anti-LcrV antibody inhibits delivery of Yops by Yersinia pestis KIM5 by directly promoting phagocytosis. Infect Immun 73, 6127-6137.

Damasko, C., Konietzny, A., Kaspar, H., Appel, B., Dersch, P. \& Strauch, E. (2005). Studies of the efficacy of enterocoliticin, a 
phage-tail like bacteriocin, as antimicrobial agent against Yersinia enterocolitica serotype $\mathrm{O} 3$ in a cell culture system and in mice. $J$ Vet Med B Infect Dis Vet Public Health 52, 171-179.

Dennis, D. T., Gratz, N., Poland, J. D. \& Tikhomirov, E. (1999). Plague Manual: Epidemiology, Distribution, Surveillance and Control. Geneva: World Health Organization.

d'Herelle, F. (1925). Essai de traitement de la peste bubonique par le bacteriophage. La Presse Medicale 84, 1393-1394 (in French).

Diatlov, I. A. \& Antonova, O. A. (1999). The detection and characteristics of the Yersinia pestis antigen exhibiting the properties of S-layer proteins. Zh Mikrobiol Epidemiol Immunobiol 4, 90-91 (in Russian).

Dmitrovskii, V. G. (1994). Toxic component of pathogenesis of plague infectious process: infective toxic shock. In Prophylaxis and Means of Prevention of Plague, pp. 15-16. Edited by V. M. Stepanov. Almaty, Kazakhstan: Scientific-Manufacturing Association of the Plague-Control Establishments (in Russian).

Domaradskii, I. V. (1993). Plague: Contemporary State, Assumptions, Problems. Saratov, Russia: Saratov Medical Institute Press (in Russian).

Domaradskii, I. V. (1998). Plague. Moscow: Meditsina Press (in Russian).

Drancourt, M., Roux, V., Dang, L. V. \& 7 other authors (2004). Genotyping, Orientalis-like Yersinia pestis, and plague pandemics. Emerg Infect Dis 10, 1585-1592.

Ehrenkranz, N. F. \& Meyer, K. F. (1955). Studies on immunization against plague, VIII: study of three immunizing preparations in protecting primates against pneumonic plague. J Infect Dis 96, 138-144.

Ferreras, J. A., Ryu, J. S., Lello, F. D., Tan, D. S. \& Quadri, L. E. (2005). Small-molecule inhibition of siderophore biosynthesis in Mycobacterium tuberculosis and Yersinia pestis. Nat Chem Biol 1, 29-32.

Filippov, A. A., Elliott, J. M., Bobrov, A. G., Kirillina, O. A., Motin, V. L., Chain, P. S. \& Garcia, E. (2005). Description of the genomic nucleotide sequence of the plague diagnostic bacteriophage, L-413C. The Problems of Particularly Dangerous Infections (Saratov) 90, 49-52 (in Russian).

Fimiani, V., Cavallaro, A., Ainis, T., Baranovskaia, G., Ketlinskaya, O. \& Kozhemyakin, L. (2002). Immunomodulatory effect of glutoxim on some activities of isolated human neutrophils and in whole blood. Immunopharmacol Immunotoxicol 24, 627-638.

Finlay, B. B. \& Falkow, S. (1997). Common themes in microbial pathogenicity revisited. Microbiol Mol Biol Rev 61, 136-169.

Flu, P. C. (1929). Antipest bakteriophag und die prophylaxe und therapie der experimentellen pest. Zentbl Bakteriol I Orig 113, 468473 (in German).

Fonquernie, I. (1932). Essais de traitement de la peste par le bacteriophage. Bull Sol Pathol Exot 25, 677 (in French).

Frean, J., Klugman, K. P., Arntzen, L. \& Bukofzer, S. (2003). Susceptibility of Yersinia pestis to novel and conventional antimicrobial agents. J Antimicrob Chemother 52, 294-296.

Friedlander, A. M., Welkos, S. L., Worsham, P. L., Andrews, G. P., Heath, D. G., Anderson, G. W., Jr, Pitt, M. L., Estep, J. \& Davis, K. (1995). Relationship between virulence and immunity as revealed in recent studies of the F1 capsule of Yersinia pestis. Clin Infect Dis $\mathbf{2 1}$ (Suppl. 2), S178-S181.

Gage, K. L. \& Kosoy, M. Y. (2005). Natural history of plague: perspectives from more than a century of research. Annu Rev Entomol 50, 505-528.

Galimand, M., Guiyoule, A., Gerbaud, G., Rasoamanana, B., Chanteau, S., Carniel, E. \& Courvalin, P. (1997). Multiple antibiotic resistance in Yersinia pestis mediated by a self-transferable plasmid. $N$ Engl J Med 337, 677-680.
Garcia, E., Elliott, J. M., Ramanculov, E., Chain, P. S., Chu, M. C. \& Molineux, I. J. (2003). The genome sequence of Yersinia pestis bacteriophage $\phi$ A1122 reveals an intimate history with the coliphage T3 and T7 genomes. J Bacteriol 185, 5248-5262.

Goode, D., Allen, V. M. \& Barrow, P. A. (2003). Reduction of experimental Salmonella and Campylobacter contamination of chicken skin by application of lytic bacteriophages. Appl Environ Microbiol 69, 5032-5036.

Green, M., Rogers, D., Russell, P., Stagg, A. J., Bell, D. L., Eley, S. M., Titball, R. W. \& Williamson, E. D. (1999). The SCID/Beige mouse as a model to investigate protection against Yersinia pestis. FEMS Immunol Med Microbiol 23, 107-113.

Guiyoule, A., Grimont, F., Iteman, I., Grimont, P. D., Lefèvre, M. \& Carniel, E. (1994). Plague pandemics investigated by ribotyping of Yersinia pestis strains. J Clin Microbiol 32, 634-641.

Hardaway, R. M. (1982). Pathology and pathophysiology of disseminated intravascular coagulation. In Pathophysiology of Shock, Anoxia and Ischaemia, pp. 186-197. Edited by R. A. Cowley \& B. F. Trump. Baltimore, MD: Williams \& Wilkins.

Hill, J., Leary, S. E. C., Griffin, K. F., Williamson, E. D. \& Titball, R. W. (1997). Regions of Yersinia pestis $\mathrm{V}$ antigen that contribute to protection against plague identified by passive and active immunization. Infect Immun 65, 4476-4482.

Hill, J., Eyles, J. E., Elvin, S. J., Healey, G. D., Lukaszewski, R. A. \& Titball, R. W. (2006). Administration of antibody to the lung protects mice against pneumonic plague. Infect Immun 74, 3068-3070.

Hinnebusch, B. J. (2003). Transmission factors: Yersinia pestis genes required to infect the flea vector of plague. Adv Exp Med Biol 529, 55-62.

Hinnebusch, B. J., Rosso, M. L., Schwan, T. G. \& Carniel, E. (2002). High-frequency conjugative transfer of antibiotic resistance genes to Yersinia pestis in the flea midgut. Mol Microbiol 46, 349-354.

Hornibrook, J. W. (1946). Streptomycin in experimental plague. Publ Health Rep 61, 535-538.

Hurtle, W., Lindler, L., Fan, W., Shoemaker, D., Henchal, E. \& Norwood, D. (2003). Detection and identification of ciprofloxacinresistant Yersinia pestis by denaturing high-performance liquid chromatography. J Clin Microbiol 41, 3273-3283.

Inglesby, T. V., Dennis, D. T., Henderson, D. A. \& 16 other authors (2000). Plague as a biological weapon: medical and public health management. JAMA (J Am Med Assoc) 283, 2281-2290.

Jacobs, R. F., Sowell, M. K., Moss, M. M. \& Fiser, D. H. (1990). Septic shock in children: bacterial etiologies and temporal relationships. Pediatr Infect Dis J 9, 196-200.

Jacobson, M. A. \& Young, L. S. (1986). New developments in the treatment of Gram-negative bacteremia. West J Med 144, 185-194.

Kang, A. S., Burton, D. R. \& Lerner, R. A. (1991). Combinatorial immunoglobulin libraries in phage. Methods: Companion Methods Enzymol 2, 111-118.

Kauppi, A. M., Nordfelth, R., Hagglund, U., Wolf-Watz, H. \& Elofsson, M. (2003a). Salicylanilides are potent inhibitors of type III secretion in Yersinia. Adv Exp Med Biol 529, 97-100.

Kauppi, A. M., Nordfelth, R., Uvell, H., Wolf-Watz, H. \& Elofsson, M. (2003b). Targeting bacterial virulence: inhibitors of type III secretion in Yersinia. Chem Biol 10, 241-249.

Keller, M. A. \& Stiehm, E. R. (2000). Passive immunity in prevention and treatment of infectious diseases. Clin Microbiol Rev 13, 602-614. Kienle, Z., Emody, L., Svanborg, C. \& O'Toole, P. W. (1992). Adhesive properties conferred by the plasminogen activator of Yersinia pestis. J Gen Microbiol 138, 1679-1687.

Kohler, G. \& Milstein, C. (1975). Continuous cultures of fused cells secreting antibody of predefined specificity. Nature 256, 495-497. 
Kool, J. L. (2005). Risk of person-to-person transmission of pneumonic plague. Clin Infect Dis 40, 1166-1172.

Krishna, G. \& Chitkara, R. K. (2003). Pneumonic plague. Semin Respir Infect 18, 159-167.

Kuberski, T., Robinson, L. \& Schurgin, A. (2003). A case of plague successfully treated with ciprofloxacin and sympathetic blockade for treatment of gangrene. Clin Infect Dis 36, 521-523.

Lachowicz, T. (1965). Investigations on staphylococcins. Zentbl Bakteriol Parasitenkd Infektkr Hyg Abt 1 Orig Reihe A 196, 340-351.

Lähteenmäki, K., Virkola, R., Sarén, A., Emödy, L. \& Korhonen, T. K. (1998). Expression of plasminogen activator Pla of Yersinia pestis enhances bacterial attachment to the mammalian extracellular matrix. Infect Immun 66, 5755-5762.

Leary, S. E. C., Williamson, E. D., Griffin, K. F., Russell, P., Eley, S. M. \& Titball, R. W. (1995). Active immunization with recombinant $\mathrm{V}$ antigen from Yersinia pestis protects mice against plague. Infect Immun 63, 2854-2858.

Lee, K., Gao, Y., Yao, Z. J., Phan, J., Wu, L., Liang, J., Waugh, D. S., Zhang, Z. Y. \& Burke, T. R., Jr (2003). Tripeptide inhibitors of Yersinia protein-tyrosine phosphatase. Bioorg Med Chem Lett 13, 2577-2581.

Lee, Y. M., Almqvist, F. \& Hultgren, S. J. (2003). Targeting virulence for antimicrobial chemotherapy. Curr Opin Pharmacol 3, 513-519.

Lee, K., Boovanahalli, S. K., Nam, K. Y. \& 9 other authors (2005). Synthesis of tripeptides as potent Yersinia protein tyrosine phosphatase inhibitors. Bioorg Med Chem Lett 15, 4037-4042.

Liappis, A. P., Kan, V. L., Rochester, C. G. \& Simon, G. L. (2001). The effect of statins on mortality in patients with bacteremia. Clin Infect Dis 33, 1352-1357.

Lien-Teh, W. (1926). A Treatise on Pneumonic Plague. League of Nations, Health Organisation. Printed by Berger-Levrault.

Lien-Teh, W., Chun, J. W. H., Pollitzer, R. \& Wu, C. Y. (1936). Plague: a Manual for Medical \& Public Health Workers. Shanghai.

Liles, W. C. (2001). Immunomodulatory approaches to augment phagocyte-mediated host defense for treatment of infectious diseases. Semin Respir Infect 16, 11-17.

Maher, S. \& McClean, S. (2006). Investigation of the cytotoxicity of eukaryotic and prokaryotic antimicrobial peptides in intestinal epithelial cells in vitro. Biochem Pharmacol 71, 1289-1298.

Marra, A. (2004). Can virulence factors be viable antibacterial targets? Expert Rev Anti Infect Ther 2, 61-72.

Masihi, K. N. (2000). Immunomodulatory agents for prophylaxis and therapy of infections. Int J Antimicrob Agents 14, 181-191.

Matson, J. S., Durick, K. A., Bradley, D. S. \& Nilles, M. L. (2005). Immunization of mice with YscF provides protection from Yersinia pestis infections. BMC Microbiol 5, 38.

McGeachie, J. (1970). An in vitro comparison of colicines $\mathrm{K}$ and V and some therapeutic antibiotics. Zentbl Bakteriol Parasitenkd Infektkr Hyg Abt 1 Orig Reihe A 215, 245-251.

Merx, M. W., Liehn, E. A., Janssens, U., Lutticken, R., Schrader, J., Hanrath, P. \& Weber, C. (2004). HMG-CoA reductase inhibitor simvastatin profoundly improves survival in a murine model of sepsis. Circulation 109, 2560-2565.

Meyer, K. F. (1970). Effectiveness of live or killed plague vaccines in man. Bull W H O 42, 653-666.

Meyer, K. F., Hightower, J. A. \& McCrumb, F. R. (1974). Plague immunization. VI. Vaccination with the fraction I antigen of Yersinia pestis. J Infect Dis 129 (Suppl.), S41-S45.

Miethke, M., Bisseret, P., Beckering, C. L., Vignard, D., Eustache, J. \& Marahiel, M. A. (2006). Inhibition of aryl acid adenylation domains involved in bacterial siderophore synthesis. FEBS J 273, 409-419.
Montgomerie, J. Z., Kalmanson, G. M., Harwick, H. J. \& Guze, L. B. (1973). Relation between bacteriocin production and virulence of Streptococcus faecalis var. liquefaciens. Proc Soc Exp Biol Med 144, 868-870.

Morrison, S. L. (1992). In vitro antibodies: strategies for production and application. Annu Rev Immunol 10, 239-265.

Mota-Meira, M., LaPointe, G., Lacroix, C. \& Lavoie, M. C. (2000). MICs of mutacin B-Ny266, nisin A, vancomycin, and oxacillin against bacterial pathogens. Antimicrob Agents Chemother 44, 24-29.

Mota-Meira, M., Morency, H. \& Lavoie, M. C. (2005). In vivo activity of mutacin B-Ny266. J Antimicrob Chemother 56, 869-871.

Motin, V. L., Nakajima, R., Smirnov, G. B. \& Brubaker, R. R. (1994). Passive immunity to yersiniae mediated by anti-recombinant $\mathrm{V}$ antigen and protein A-V antigen fusion peptide. Infect Immun 62, 4192-4201.

Naidu, B. P. B. \& Avari, G. R. (1932). Bacteriophage in the treatment of plague. Ind J Med Res 19, 737-748.

Nau, R. \& Eiffert, H. (2002). Modulation of release of proinflammatory bacterial compounds by antibacterials: potential impact on course of inflammation and outcome in sepsis and meningitis. Clin Microbiol Rev 15, 95-110.

Naumov, A. V. \& Samoilova, L. V. (1992). Manual on Plague Prophylaxis. Saratov, Russia: Russian Research Anti-Plague Institute 'Microbe' (in Russian).

Naumov, A. V., Ledvanov, M. Yu. \& Drozdov, I. G. (1992). Plague Immunology. Saratov, Russia: Russian Research Anti-Plague Institute 'Microbe' (in Russian).

Navas, E. (2002). Problems associated with potential massive use of antimicrobial agents as prophylaxis or therapy of a bioterrorist attack. Clin Microbiol Infect 8, 534-539.

Nikolaev, N. I. (1972). Manual on Plague Prophylaxis. Saratov, USSR: All-Union Research Anti-Plague Institute 'Microbe' (in Russian).

Nordfelth, R., Kauppi, A. M., Norberg, H. A., Wolf-Watz, H. \& Elofsson, M. (2005). Small-molecule inhibitors specifically targeting type III secretion. Infect Immun 73, 3104-3114.

Ofek, I., Hasty, D. L. \& Sharon, N. (2003). Anti-adhesion therapy of bacterial diseases: prospects and problems. FEMS Immunol Med Microbiol 38, 181-191.

Oyston, P. C. F., Dorrell, N., Williams, K., Li, S.-R., Green, M., Titball, R. W. \& Wren, B. W. (2000). The response regulator PhoP is important for survival under conditions of macrophage-induced stress and virulence in Yersinia pestis. Infect Immun 68, 3419-3425.

Parkhill, J., Wren, B. W., Thomson, N. R. \& 32 other authors (2001). Genome sequence of Yersinia pestis, the causative agent of plague. Nature 413, 523-527.

Payne, D., Tatham, D., Williamson, E. D. \& Titball, R. W. (1998). The pH 6 antigen of Yersinia pestis binds to $\beta 1$-linked galactosyl residues in glycosphingolipids. Infect Immun 66, 4545-4548.

Perry, R. D. \& Fetherston, J. D. (1997). Yersinia pestis - etiologic agent of plague. Clin Microbiol Rev 10, 35-66.

Philipovskiy, A. V., Cowan, C., Wulff-Strobel, C. R., Burnett, S. H., Kerschen, E. J., Cohen, D. A., Kaplan, A. M. \& Straley, S. C. (2005). Antibody against $\mathrm{V}$ antigen prevents Yop-dependent growth of Yersinia pestis. Infect Immun 73, 1532-1542.

Pollitzer, R. (1954). Plague. W H O Monogr Ser 22, 1-698.

Porat, R., McCabe, W. R. \& Brubaker, R. R. (1995). Lipopolysaccharideassociated resistance to killing of yersiniae by complement. J Endotoxin Res 2, 91-97.

Portnoy, D. A. \& Falkow, S. (1981). Virulence-associated plasmids from Yersinia enterocolitica and Yersinia pestis. J Bacteriol 148, 877-883.

Rackow, E. C. \& Astiz, M. E. (1991). Pathophysiology and treatment of septic shock. JAMA (J Am Med Assoc) 266, 548-554. 
Raoult, D., Aboudharam, G., Crubezy, E., Larrouy, G., Ludes, B. \& Drancourt, M. (2000). Molecular indentification by 'suicide PCR' of Yersinia pestis as the agent of medieval Black Death. Proc Natl Acad Sci U S A 97, 12800-12803.

Riley, M. A. \& Wertz, J. E. (2002). Bacteriocins: evolution, ecology, and application. Annu Rev Microbiol 56, 117-137.

Robinson, V. L., Oyston, P. C. \& Titball, R. W. (2005). A dam mutant of Yersinia pestis is attenuated and induces protection against plague. FEMS Microbiol Lett 252, 251-256.

Roggenkamp, A., Geiger, A. M., Leitritz, L., Kessler, A. \& Heesemann, J. (1997). Passive immunity to infection with Yersinia spp. mediated by anti-recombinant $\mathrm{V}$ antigen is dependent on polymorphism of $\mathrm{V}$ antigen. Infect Immun 65, 446-451.

Rojas, C. M., Ham, J. H., Deng, W. L., Doyle, J. J. \& Collmer, A. (2002). $\mathrm{Hec} A$, a member of a class of adhesins produced by diverse pathogenic bacteria, contributes to the attachment, aggregation, epidermal cell killing, and virulence phenotypes of Erwinia chrysanthemi EC16 on Nicotiana clevelandii seedlings. Proc Natl Acad Sci U S A 99, 13142-13147.

Rudnev, G. P. (1940). Clinical Picture of Plague. Moscow, Leningrad, Russia: Medgiz (in Russian).

Russell, P., Eley, S. M., Green, M. \& 8 other authors (1998). Efficacy of doxycycline and ciprofloxacin against experimental Yersinia pestis infection. J Antimicrob Chemother 41, 301-305.

Ryan, M. P., Flynn, J., Hill, C., Ross, R. P. \& Meaney, W. J. (1999). The natural food grade inhibitor, lacticin 3147 , reduced the incidence of mastitis after experimental challenge with Streptococcus dysgalactiae in nonlactating dairy cows. J Dairy Sci 82, 2625-2631.

Ryzhko, I. V., Samokhodkina, E. D., Tsuraeva, R. I., Shcherbaniuk, A. I. \& Tsetskhladze, N. S. (1998). Characteristics of etiotropic therapy of plague infection induced by atypical strains of $\mathrm{F}^{-}$phenotype plague microbe. Antibiot Khimioter 43, 24-28 (in Russian).

Sabhnani, L. \& Rao, D. N. (2000). Identification of immunodominant epitope of $\mathrm{F} 1$ antigen of Yersinia pestis. FEMS Immunol Med Microbiol 27, 155-162.

Sabhnani, L., Manocha, M., Sridevi, K., Shashikiran, D., Rayanade, R. \& Rao, D. N. (2003). Developing subunit immunogens using B and $\mathrm{T}$ cell epitopes and their constructs derived from the F1 antigen of Yersinia pestis using novel delivery vehicles. FEMS Immunol Med Microbiol 38, 215-229.

Simpson, W. J., Thomas, R. E. \& Schwan, T. G. (1990). Recombinant capsular antigen (fraction 1) from Yersinia pestis induces a protective antibody response in BALB/c mice. Am J Trop Med Hyg 43, 389-396.

Sing, A., Rost, D., Tvardovaskaia, N., Roggenkamp, A., Wiedemann, A., Kirschning, C. J., Aepfelbacher, M. \& Heesemann, J. (2002). Yersinia V-antigen exploits toll-like receptor 2 and CD14 for interleukin 10-mediated immunosuppression. J Exp Med 196, 1017-1024.

Skurnik, M. \& Strauch, E. (2006). Phage therapy: facts and fiction. Int J Med Microbiol 296, 5-14.

Smith, H. W. (1974). A search for transmissible pathogenic characters in invasive strains of Escherichia coli: the discovery of a plasmidcontrolled toxin and a plasmid-controlled lethal character closely associated, or identical, with colicin V. J Gen Microbiol 83, 95-111.

Sodhi, A., Sharma, R. K., Batra, H. V. \& Tuteja, U. (2004). Mechanism of rLcrV and rYopB mediated immunosuppression in murine peritoneal macrophages. Mol Immunol 41, 767-774.

Stern, N. J., Svetoch, E. A., Eruslanov, B. V., Kovalev, Y. N., Volodina, L. I., Perelygin, V. V., Mitsevich, E. V., Mitsevich, I. P. \& Levchuk, V. P. (2005). Paenibacillus polymyxa purified bacteriocin to control Campylobacter jejuni in chickens. J Food Prot 68, 1450-1453.

Steward, J., Lever, M. S., Russell, P., Beedham, R. J., Staga, A. J., Taylor, R. R. \& Brooks, T. J. G. (2004). Efficacy of the latest fluoroquinolones against experimental Yersinia pestis. Int J Antimicrob Agents 24, 609-612.

Straley, S. C. (1993). Adhesins in Yersinia pestis. Trends Microbiol 1, 285-286.

Suga, H. \& Smith, K. M. (2003). Molecular mechanisms of bacterial quorum sensing as a new drug target. Curr Opin Chem Biol 7, 586-591.

Sulakvelidze, A. (2005). Phage therapy: an attractive option for dealing with antibiotic-resistant bacterial infections. Drug Discov Today 10, 807-809.

Summers, W. C. (1999). Felix d'Herelle and the Origins of Molecular Biology. New Haven, CT: Yale University Press.

Summers, W. C. (2001). Bacteriophage therapy. Annu Rev Microbiol 55, 437-451.

Tagg, J. R. \& McGiven, A. R. (1972). Some possible autoimmune mechanisms in rheumatic carditis. Lancet 2, 686-688.

Tagg, J. R., Dajani, A. S. \& Wannamaker, L. W. (1976). Bacteriocins of Gram-positive bacteria. Bacteriol Rev 40, 722-756.

Thomas, R. \& Brooks, T. (2004). Common oligosaccharide moieties inhibit the adherence of typical and atypical respiratory pathogens. J Med Microbiol 53, 833-840.

Thomas, R. \& Brooks, T. (2006). Attachment of Yersinia pestis to human respiratory cell lines is inhibited by certain oligosaccharides. J Med Microbiol 55, 309-315.

Turnowsky, F., Drews, J., Eich, F. \& Hogenauer, G. (1973). In vitro inactivation of ascites ribosomes by colicin E3. Biochem Biophys Res Commun 52, 327-334.

Une, T. \& Brubaker, R. R. (1984). Roles of V antigen in promoting virulence and immunity in yersiniae. J Immunol 133, 2226-2230.

Van Amersfoort, E. S., Van Berkel, T. J. \& Kuiper, J. (2003). Receptors, mediators, and mechanisms involved in bacterial sepsis and septic shock. Clin Microbiol Rev 16, 379-414.

Viboud, G. I. \& Bliska, J. B. (2005). Yersinia outer proteins: role in modulation of host cell signaling responses and pathogenesis. Annu Rev Microbiol 59, 69-89.

Vincent, J.-L., Roman, A. \& Kahn, R. J. (1990). Dobutamine administration in septic shock: addition to a standard protocol. Crit Care Med 18, 689-693.

Weeks, S., Hill, J., Friedlander, A. \& Welkos, S. (2002). Anti-V antigen antibody protects macrophages from Yersinia pestis-induced cell death and promotes phagocytosis. Microb Pathog 32, 227-237.

Welty, T. K., Grabman, J., Kompare, E., Wood, G., Welty, E., Van Duzen, J., Rudd, P. \& Poland, J. (1985). Nineteen cases of plague in Arizona: a spectrum including ecthyma gangrenosum due to plague and plague in pregnancy. West J Med 142, 641-646.

Wheeler, A. P. \& Bernard, G. R. (1999). Treating patients with severe sepsis. N Engl J Med 340, 207-214.

Williamson, E. D. (2001). Plague vaccine research and development. J Appl Microbiol 91, 606-608.

Williamson, E. D., Flick-Smith, H. C., Lebutt, C. \& 7 other authors (2005). Human immune response to a plague vaccine comprising recombinant $\mathrm{F} 1$ and $\mathrm{V}$ antigens. Infect Immun 73, 3598-3608.

Winfield, M. D., Latifi, T. \& Groisman, E. A. (2005). Transcriptional regulation of the 4-amino-4-deoxy-L-arabinose biosynthetic genes in Yersinia pestis. J Biol Chem 280, 14765-14772.

Winslow, E. J., Loeb, H. S., Rahimtoola, S. H., Kamath, S. \& Gunnar, R. M. (1973). Hemodynamic studies and results of therapy in 50 patients with bacteremic shock. Am J Med 54, 421-432.

Wong, J. D., Baresh, J. R., Sandfort, R. F. \& Janda, J. M. (2000). Susceptibilities of Yersinia pestis strains to 12 antimicrobial agents. Antimicrob Agents Chemother 44, 1995-1996. 
WHO (1970). Health Aspects of Chemical and Biological Weapons: Report of a WHO Group of Consultants. Geneva: World Health Organization.

WHO Expert Committee on Plague (1970). Fourth report. World Health Organ Tech Rep Ser 447, 1-25.

Xie, J., Comeau, A. B. \& Seto, C. T. (2004). Squaric acids: a new motif for designing inhibitors of protein tyrosine phosphatases. Org Lett 6, 83-86.

Yersin, A. (1894). La peste bubonique à Hong-Kong. Ann Inst Pasteur 8, 662-667 (in French).

Yersin, A. (1897). Sur la peste bubonique (sérothérapie). Ann Inst Pasteur 11, 81-93 (in French).

Yersin, A., Calmette, A. \& Borrel, A. (1895). La peste bubonique (deuxiéme note). Ann Inst Pasteur 9, 589-592 (in French).
Young, R. (1992). Bacteriophage lysis: mechanism and regulation. Microbiol Rev 56, 430-481.

Zav'yalov, V., Denesyuk, A., Zav'yalova, G. \& Korpela, T. (1995). Molecular modeling of the steric structure of the envelope F1 antigen of Yersinia pestis. Immunol Lett 45, 19-22.

Zav'yalov, V. P., Abramov, V. M., Cherepanov, P. G., Spirina, G. V., Chernovskaya, T. V., Vasiliev, A. M. \& Zav'yalov, G. A. (1996). pH6 antigen (PsaA protein) of Yersinia pestis, a novel bacterial Fcreceptor. FEMS Immunol Med Microbiol 14, 53-57.

Zhemchugov, V. Ye. (2004). How We Developed Chemical Vaccines: Notes about Today's 'Microbe Hunters'. Moscow: Nauka (in Russian).

Zietz, B. P. \& Dunkelberg, H. (2004). The history of the plague and the research on the causative agent Yersinia pestis. Int J Hyg Environ Health 207, 165-178. 